\title{
Elisa Pallottini
}

\section{The Epigraphic Presence on the Borghorst Cross (c. 1050)}

Around 1050, a magnificent crucifix was donated to the former female collegiate church of St Nikomedes (now parish church) at Borghorst, Westphalia (Fig. 1-2). ${ }^{1}$ The Borghorst Cross, as this crucifix is more commonly known, is a reliquary splendidly decorated with gold, gems and precious stones, as was a long-standing custom in church practice. Just like many other reliquaries of the same period, it includes inscriptions to identify the images depicted on both sides of the cross and the relics concealed inside. These inscriptions form the subject of this paper. Using the Borghorst Cross as a case study, this article hopes to contribute to a better understanding of the interplay between inscriptions and relics, by exploring how writing, as both a textual and visual device, interacted with the physical context in which the relics were placed, contributed to its meanings, and engaged medieval audiences. ${ }^{2}$ The type of context that concerns us here is, first, that of the portable reliquary and, second, the wider architectural and liturgical context in which the inscribed reliquary was displayed and set in motion, as an object meant to be seen and contemplated by the faithful who came to pray in the church.

Although the focus is on one case study, the methodology of this paper has been developed on the basis of a large corpus of inscribed reliquaries from western medieval Europe. ${ }^{3}$ It addresses the inscriptions as material components of all reliquaries, exploring their textual and visual functioning within the larger system to which they belong. Using the epigraphic programme of the Borghorst Cross, I argue that the ways in which epigraphic texts on reliquaries conveyed meanings and contributed to these objects' significance and functions, were inherently linked to the interactions between the inscribed text and its context, including the inscriptions' interactions with the surrounding images, materials, decorations, the shape of the reliquary, the relics concealed inside, and the faithful, the author or spectators of the epigraphic object. The cross of St Nikomedes allows me to explore some of these interactions,

1 For further information on the church, see Jázai 1988.

2 In recent years, scholars have devoted considerable attention to the materiality of writing, its visual properties and interactions with the monumental context. This is the main research focus of the Heidelberg Collaborative Research Center 933 "Material Text Cultures. Materiality and Presence of Writing in Non-Typographical Societies”; see, for instance, in the MTK-series, Frese/Keil/Krüger 2014; for inscriptions in particular, see Berti et al. 2017. See also the collection of essays on inscriptions from a wide range of contexts across the medieval world, in Eastmond 2015a. Studies on the interactions between inscriptions and reliquaries from the Byzantine world include Hostetler 2012.

3 This paper is a result of my postdoctoral research project on inscriptions and the cult of relics in western medieval Europe (2014-2017), as part of the VIDI-project Mind over Matter. Debates about relics as sacred objects, c. 350-c.1150, led by Dr. Janneke Raaijmakers at Utrecht University (2013-2019). 


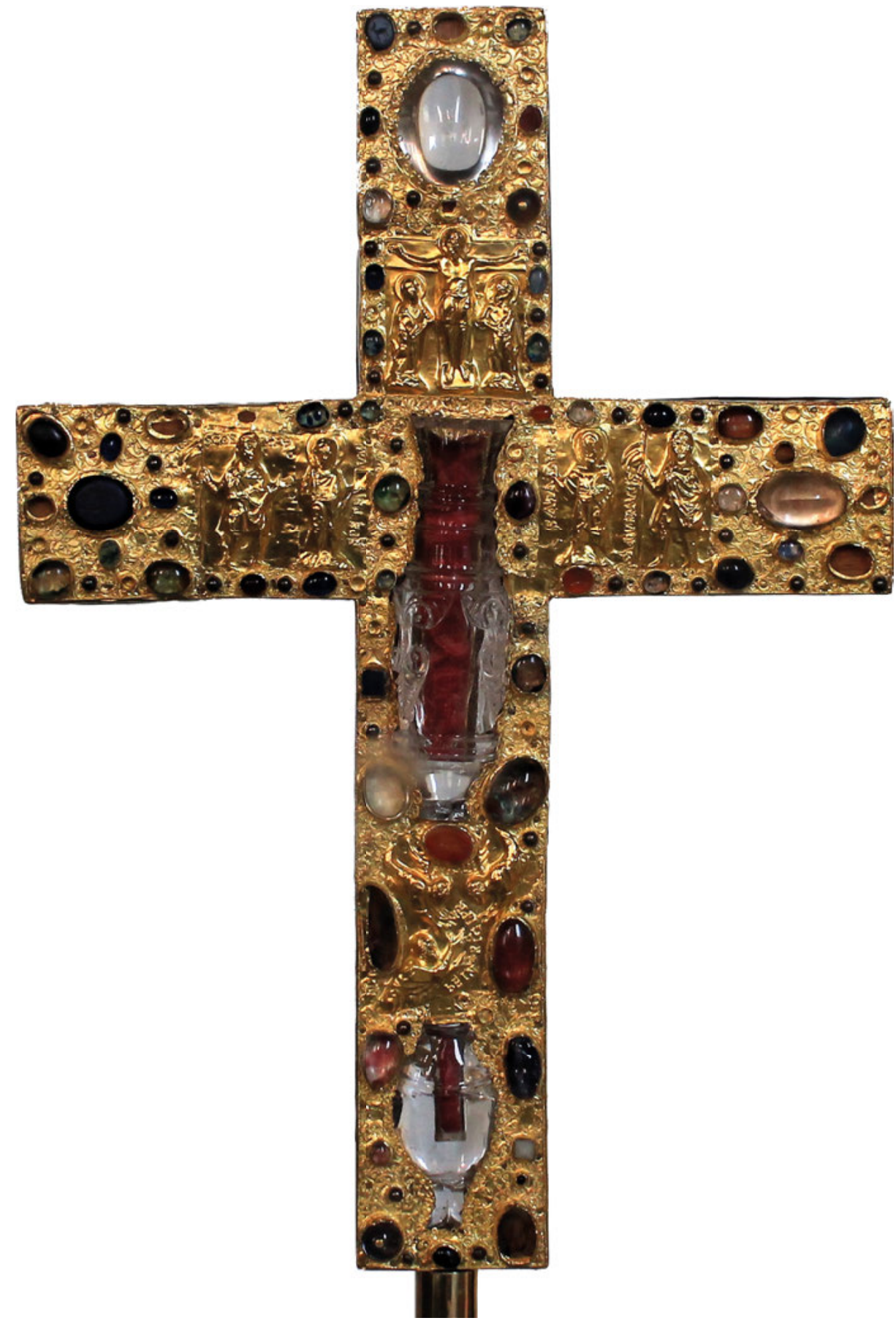

Fig. 1: Borghorst (Germany), cross reliquary from St Nikomedes, obverse. 


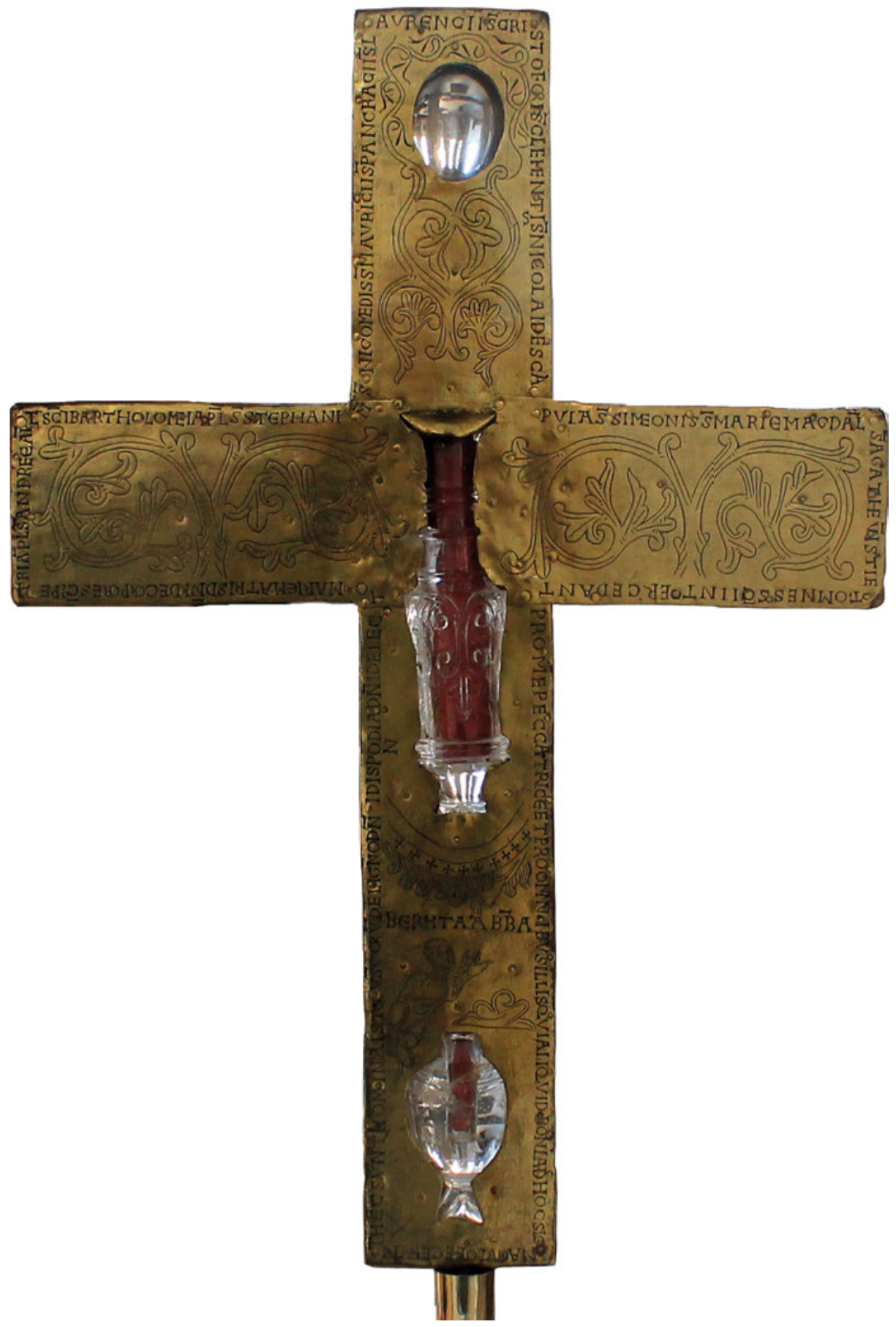

Fig. 2: Borghorst (Germany), cross reliquary from St Nikomedes, reverse. 
focusing more on the impact of the epigraphic presence on the construction of the reliquary than on the visual impact of the inscribed reliquary within its appropriate context of veneration.

While the Borghorst Cross is one of the finest exemplars of reliquaries from western medieval Europe, it has, strangely enough, received only modest attention from scholars. The best-known studies on the cross focus on the symbolism associated with the precious materials used in its design, particularly the rock crystal, and on the cross's date of composition and stylistic features. ${ }^{4}$ The crucifix's inscriptions have been all but ignored in the literature. The slight attention they have received has been directed to their textual content only, despite the fact that the remarkable physical appearance of the inscriptions indicates that they worked simultaneously on multiple levels that did not necessarily require reading. ${ }^{5}$

This paper therefore constitutes a first attempt to understand the cross in its epigraphic dimension, and to answer the question how its inscriptions were meant to 'work'. To be able to answer this question properly, I will look not only at the inscriptions' textual content, but also at the technique used for making them, their spatial organization and their correlation with the adjacent images, materials, and other inscriptions. Together, the collected observations reveal that the reliquary's inscriptions worked on many levels to construct and express the cross's multivalent messages conveyed by its intricate relationship of texts, writing, imageries and relics.

\section{Reading the Borghorst Cross}

The Borghorst Cross is a Latin cruciform reliquary measuring $41.1 \times 28.4 \mathrm{~cm}^{6}{ }^{6}$ It consists of a wooden core over which have been applied gold sheets on the front and gilded copper sheets on the back. Two Fatimid rock crystal flasks, filled with relics wrapped in red silk, are incorporated into the vertical shaft and are visible from both sides; one flask of elongated shape is placed at the crossing of the arms, while another smaller flask is inserted at the foot of the cross. A rock crystal cabochon is inserted into the upper shaft, in axis with the vessels. On the obverse, the narrative

4 For a detailed analysis of the use of the rock crystal, its symbolism and interaction with the iconographic programme of the Borghorst Cross, see Gerevini 2014; see also Bagnoli 2011, 138. For the cross's dating and stylistics, see Eickel 1968; Lasko 1994, 134-135; Reudenbach 2009, 354, Nr. 126 (Andrea Schaller); Bagnoli et al. 2011, 174, Nr.77 (Martina Bagnoli);Althoff et al. 2012, 147, Nr. 27 (Gerd Althoff); Kurtze 2017, 70f., with further bibliography.

5 For the transcription and translation of the inscriptions, see further in this article; for other editions, see, for instance, Eickel 1968; Bagnoli et al. 2011, 174, Nr.77 (Martina Bagnoli), with further bibliography; Kurtze 2017, 72, 77.

6 Cf. Bagnoli et al. 2011, 174, Nr. 77 (Martina Bagnoli). The reliquary was stolen in 2013 and recovered in 2017, see Roll 2017. The current location of the cross is unknown. 
presents embossed images and inscriptions framed by multicoloured stones and pearls set within a subtle pattern of filigree (Fig. 1). The reverse displays engraved figurative motifs framed by a set of two inscriptions, all filled with a black pigment on a gilded background (Fig. 2). The inscriptions are of two types. One comprises nominal inscriptions that identify the images of celestial entities and of the two patrons of the reliquary, while the other is a list of the relics contained in the cross, ending with a prayer for intercession.

The crucifix was commissioned around 1050 by Abbess Bertha, possibly the third of this name since the foundation of the abbey in $968,{ }^{7}$ to house a group of seventeen relics which the Holy Roman Emperor Henry III (d. 1056) donated to the community shortly after he ascended to the throne in $1046 .^{8}$ The named images of Emperor Henry and Abbess Bertha figure on the front and the back of the cross at the bottom of the vertical shaft, a common position for donors' portraits on cross reliquaries. ${ }^{9}$ While the identity of the artist(s) and the exact location of the workshop responsible for the execution of the cross cannot be determined with certainty, it has generally been associated with Essen. Stylistically, the reliquary is indeed similar to a group of liturgical objects commissioned by Abbess Theophanu of the abbey in Essen around 1040, particularly with an altar cross and a binding for a Gospel book. ${ }^{10}$ This again suggests that the crucifix was manufactured in the central decades of the $11^{\text {th }}$ century.

The palaeography of the inscriptions also points towards this dating, showing a typical eleventh-century majuscule script mixing capital letters with a few uncial and gothic forms $(H, E, O R)$. Despite the different aspect of letters due to the use of a different writing technique on each side, all inscriptions seem to have been realized at the same moment when the cross was produced, as their palaeography, textual contents, and spatial distribution show. The texts are intimately linked to the reliquary's visual programme, in such a way that, without its inscriptions, the cross would have had neither the same meaning nor the same appearance. Because they are conceived as parts of a larger ensemble, these texts work in concert with the adjacent images and materials.

On the obverse, the images and names of Saints Cosmas, Peter, Paul and Damian are arranged in couples along the horizontal arm, on both sides of the reddened ampulla; they are all depicted in standing position holding attributes. From the left to the right, the texts read:

\footnotetext{
7 Kurtze 2017, 72f.

8 The dating follows Kurtze 2017, 72f.; see also Bagnoli et al. 2011, 174, Nr. 77 (Martina Bagnoli).

9 Other examples from Germany are the Cross of Abbess Mathilda of Essen and Duke Otto of Swabia (c. 980), the (second) Cross of Abbess Mathilda (beginning $11^{\text {th }}$ c.), the Cross of Countess Gertrude of Brunswick (c. 1038), and the Cross of Bishop Herimann and Abbess Ida from St Maria im Kapitol at Cologne (second half $11^{\text {th }} \mathrm{c}$.).

10 Kurtze 2017, 72f.; Althoff et al. 2012, 144, Nr. 26 (Gerd Althoff).
} 
S(anctus) COSMAS
S(anctus) PETRVS
S(anctus) PAVLVS
S(anctus) DAMIANVS

Each nominal group consists of a single line that extends on either side or next to the body or attribute of a saint, a common layout for nominal inscriptions identifying images depicted in mural paintings and on metal works since the Carolingian period. ${ }^{11}$ The titulus of Saint Cosmas is arranged in a horizontal line to the left and right of the head of the saint, who is represented without the nimbus and holding a banner, like his companion Damian on the opposite side of the row. Those of the other three saints run perpendicularly either from the bottom to the top, in the case of Saint Peter on the left-hand side, or from the top to the bottom, in the case of Saints Paul and Damian on the right-hand side. We may not be able to understand entirely the choices underlying the layout of the inscriptions, but if some common patterns can be found, one of them is that the vertical inscriptions are arranged in such a way that letters are always oriented towards the center of the cross, so as to emphasize the correlation of the saints with the relics collected in the central ampulla. It has been suggested that these gold reliefs, together with the one depicting the Crucifixion above the central flask, were originally part of another artefact, and were incorporated into the cross at the time of its execution. ${ }^{12}$ If this was the case, the inscriptions must have been added to the spolia intaglios at the moment of their reuse on the reliquary. Hitherto, the images and the inscriptions have been considered by scholars as an indistinct unit, but the layout of the scripts and their graphic analogies with the other texts inscribed on the reliquary suggest that these nominal inscriptions have been expressly designed for this cross.

The Crucifixion occupying the space between the upper cabochon and the central flask is the only scene on the cross that appears to be without inscriptions (Fig. 3). The absence of writing from this scene is all the more noticeable considering the extraordinary recurrence with which the titulus of the Cross or Christ appears in the Crucifixions depicted on all kinds of media since the early Middle Ages. ${ }^{13}$

Because scholars have questioned that the relief was an original part of the cross, it is not possible to determine whether or not there might have been an inscription to accompany the Crucifixion in the original setting. ${ }^{14}$ Be this as it may, the absence of writing here demonstrates that the inclusion of inscriptions was not obligatory, nor homogeneous, but was a matter of choice. Many reliquaries indeed bear no inscriptions, nor was the use of writing on a single object always consistent-note that just

11 Debiais 2017a, 28-30.

12 See the discussion in Kurtze 2017, 76, in relation also to the restoration of the cross in 1975-1976.

13 Cf. Debiais 2017a, 82-86. See also Boston 2003.

14 For instance, the titulus crucis or the (double) trigram IHS (XPS). 


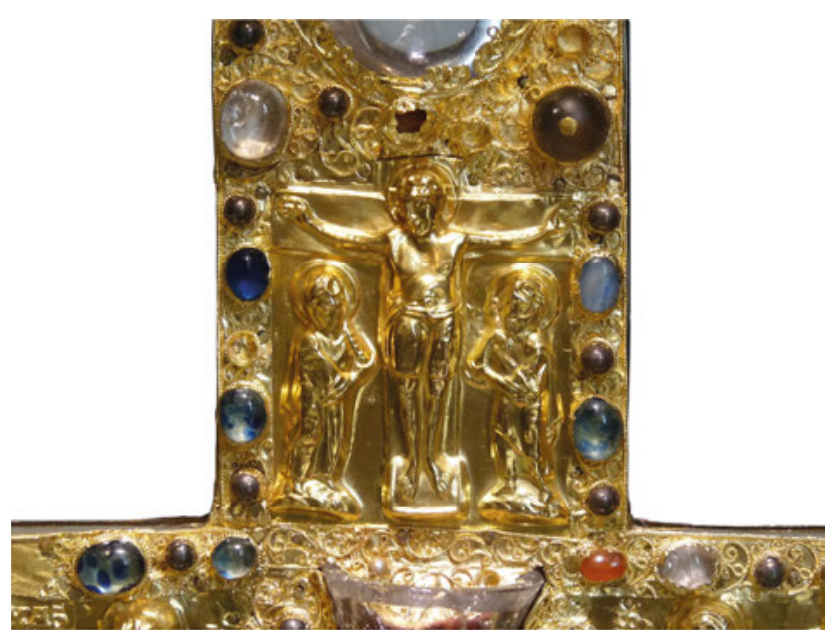

Fig. 3: Borghorst Cross, obverse, detail of the Crucifixion on the upper arm.

some parts were inscribed, and others were not. Although the choices are not always easy to reconstruct, they are different in each case and may rely on both pragmatic and symbolic reasons. They are, as such, expressions of the significance of writing. Inscriptions, whenever present, are never accidental or superfluous records, but contribute to the creation of a meaning, even when the texts could not be easily seen or read, or were called upon to identify images that might have been easily recognizable in themselves.

On the lower shaft, a scene displaying a kneeling figure being received by two angels completes the narrative (Fig.4). Two inscriptions identify the figures respectively as:

HEINRIC(us) I(m)P(e)R(ator)

ANG(e)LI

Texts and figurative representations share the same background, with letters placed between the angels' wings, just below a red cameo, and along the outstretched arms of the Emperor, and in contact, too, with the angels' hands. The figure of the Emperor is drawn in the same praying gesture as that of a second kneeling figure on the back, both sharing the same portion of the shaft comprised between the two rock crystal flasks. The scene features the identified image of "Bertha the Abbess" with hands raised towards the blessing hand of God (Fig. 5). The text, engraved and filled in with black, reads:

BERTHA ABB(atiss)A

Placed in a horizontal line at the intersection between the kneeling figure, below, and the hand of God, above, the nominal inscription simultaneously separates and connects the two portions of the space occupied by the representations of both terrestrial 


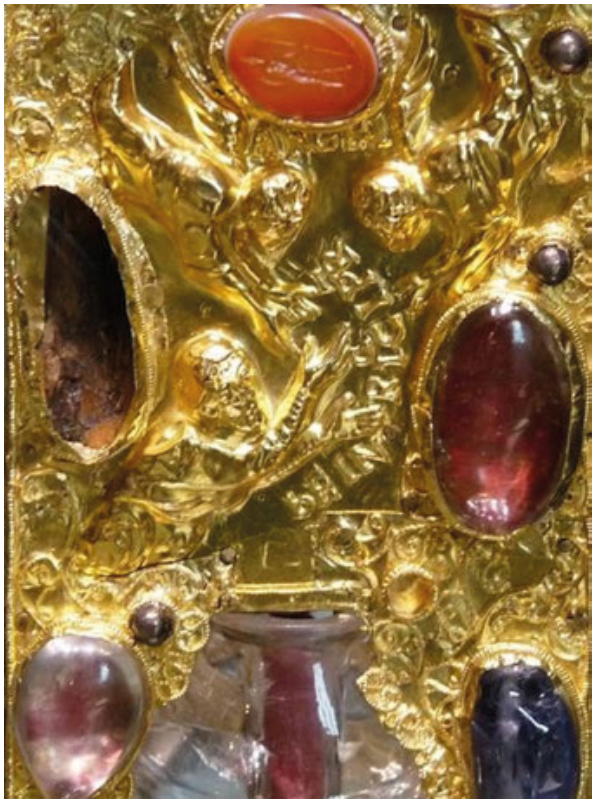

Fig. 4: Borghorst Cross, obverse, detail of the lower arm.

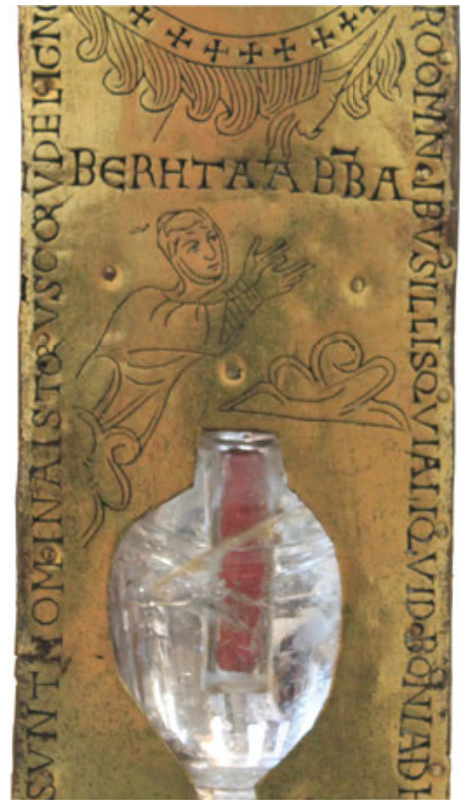

Fig. 5: Borghorst Cross, reverse, detail of the lower arm.

and celestial entities, linking the identified image of Bertha to the entire composition. It includes a vegetal scroll that expands on the upper and horizontal axes and alludes to the lignum vitae, the biblical Tree of Life, symbol of Christ's sacrifice as a source of salvation. ${ }^{15}$ Although the nominal inscription forms a syntactically independent unity, it participates in the meaning of the lengthy inscription which revolves in a clockwise direction around the back of the cross (Fig. 2). It is a list of relics, ending with the prayer for intercession addressed by Abbess Bertha to the whole community of saints. The inscription can be transcribed and translated as follows: ${ }^{16}$

15 The Tree of Life appears in Rev. 22:1-2: "Then the angel showed me the river of the water of life, bright as crystal, flowing from the throne of God and of the Lamb through the middle of the street of the city; also, on either side of the river, the tree of life with its twelve kinds of fruit, yielding its fruit each month. The leaves of the tree were for the healing of the nations”. As Stefania Gerevini pointed out, the vegetal scroll and the rock crystal flasks on the Borghorst Cross replicate the relative positions of the Tree of Life and the river; see Gerevini 2014, 96. A monumental representation of the Tree of Life can be found in the apse mosaic of San Clemente in Rome, where the relics had perhaps been inserted into the wall, as suggested by the text of the inscription that runs at the base of the apse, see Riccioni 2006.

16 My transcription and translation. The slash ( / ) indicates the change of direction of the text following the contours of the cross. The punctuation marks $(<>)$ indicate the letters placed below the line of writing. 
HEC SVNT NOMINA ISTORV(m) S(an)C(t)ORV(m) DE LIGNO D(omiI)NI DI SPO $<\mathrm{N}>\mathrm{DIA}$ D(omi)NI DE LECT/O MARIE MATRIS D(omi)NI DE CORPORE S(an)C(t)I PE/TRI AP(osto) L(i) S(ancti) ANDREE AP(osto)/L(i) S(an)C(t)I BARTHOLOMEI AP(osto)L(i) S(ancti) STEPHANI / M(artyris) / S(ancti) NICOMEDIS S(ancti) MAVRICII S(ancti) PANCRACII S(ancti) L/AVRENCII S(ancti) CRI/STOFORI S(ancti) CLEMENTI $<$ S $>$ S(ancti) NICOLAI DE SCA/ PVLA S(ancti) SIMEONIS S(anctae) MARIE MAGDAL(enae) / S(anctae) AGATHE V(irginis) ISTI E/T OMNES S(an)C(t)I INTERCEDANT / PRO ME PECCATRICE ET PRO OMNIBVS ILLIS QVI ALIQVID BONI AD HOC SIG/NACVLO FECERVN/T.

These are the names of those saints, of the wood [of the Cross] of the Lord, of the sponge of the Lord, of the bed of Mary mother of the Lord, of the body of Saint Peter apostle, of Saint Andrew apostle, of Saint Bartholomew apostle, of Saint Stephan martyr, of Saint Nicomedes, of Saint Maurice, of Saint Pancras, of Saint Lawrence, of Saint Christopher, of Saint Clement, of Saint Nicholas, of the shoulder blade of Saint Simeon, of Saint Mary Magdalene, of Saint Agatha virgin. May these and all saints intercede for me, sinner, and for all those who have done something good for this sign.

The inscription opens with the formula hec sunt nomina istorum sanctorum, asserting the nature of list of the text which incorporates the mention of the relics and the prayer of the faithful, all sharing the same graphic space. The layout of writing emphasizes the unity of the textual composition: the text, written in a continuous script, both starts and ends at the bottom left corner, revolving clockwise in a self-contained circle that encapsulates all the other textual and visual elements featured on this side of the cross. Their physical proximity and visual affinities (due to the use of the same colour and engraving technique) encourage approaching them as an integrated textual and visual programme. As a consequence, the contents that both texts and images represent are also brought together both at a physical and symbolic level.

To begin with, one should notice that, although the subject of the list is "the names of those saints", the itemized things are not names tout-court, but refer to relics of identified saints. This is not an isolated case. A number of other inscriptions use similar formulations to introduce the list of the contents of a reliquary or an altar. ${ }^{17}$ An example from Germany is the portable altar, now in the Treasury of the Residence of Munich, which the Holy Roman Emperor Henry II donated to Bamberg around 1015-1020. ${ }^{18}$ The inscription revolving around the bottom panel asserts that the altar contains the relics of the saints whose names are written down there (hic).${ }^{19}$ Similarly,

17 An earlier example can be found in the monumental relic lists of Sant'Angelo in Pescheria in Rome (c. 755), whose text begins Haec sunt nomina sanctorum quorum beneficia hic requiescunt. For the analysis of this text and other monumental inscriptions featuring a list of relics, see Pallottini 2018 (forthcoming).

18 Pictures of the altar and its inscriptions can be found in Lasko 1994, 126-127, fig. 175-177. On the altar and its symbolism, see also Hahn 2014, 46-47.

19 + IN HOC ALTARI S(an)C(t)ORV(m) REL(iquiae) C(on)TINENTVR / QVORVM HIC NOMINA SCRIPTA HABENTVR / DE LIGNO D(omi)NI REL(iquiae) S(an)C(t)I GEORGII M(artyris) S(ancti) PANCRATII M(artyris) / S(ancti) SEBASTIANI M(artyris) S(ancti) STEPHANI M(artyris) S(ancti) 


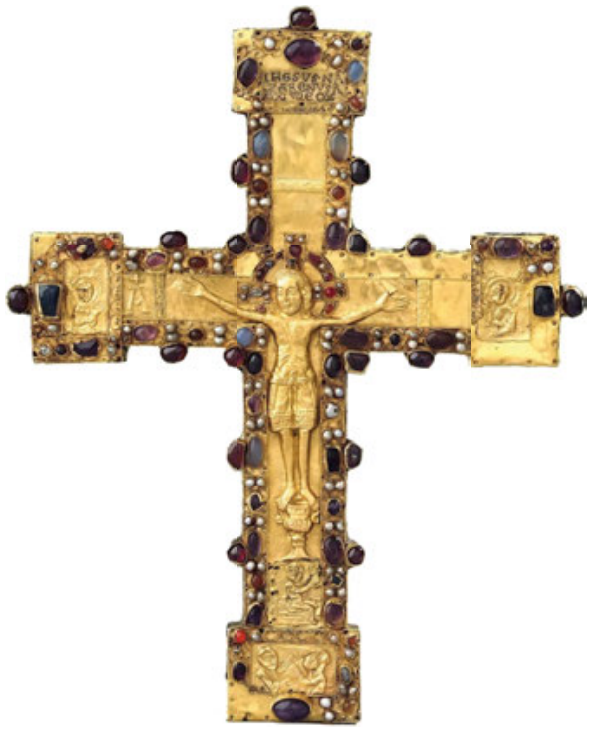

Fig. 6: Erpho Cross, reliquary, c. 1090, obverse. St Mauritz, Münster.

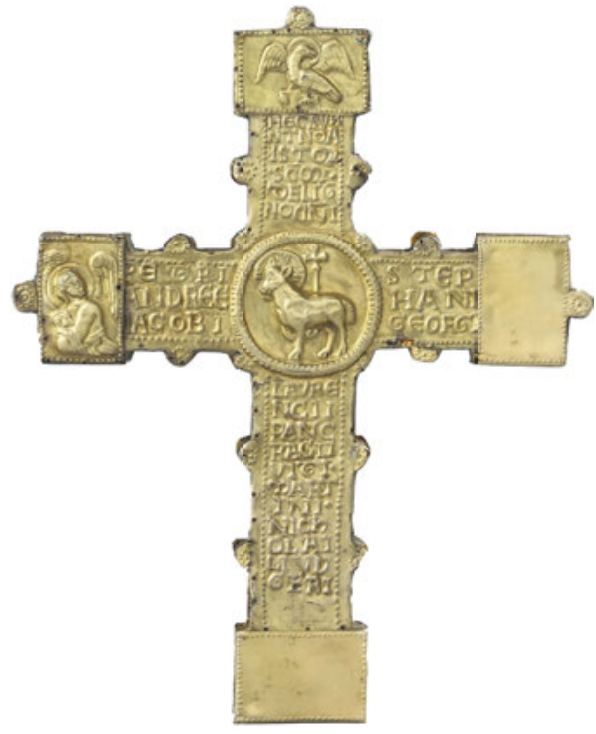

Fig. 7: Erpho Cross, reliquary, c. 1090, reverse. St Mauritz, Münster.

an inscription engraved on the inferior plate of an eleventh-century purse reliquary from Minden (Germany) introduces the list of its contents by saying that it contains the relics of the saints whose names can be read here (hic), i. e. on the bottom of the purse. ${ }^{20}$ On the so-called Erpho Cross at St Mauritz in Münster (Fig. 6-7), the formulary that opens the relic list inscribed on the back is identical to that of the Borghorst Cross: "These are the names of those saints" (Fig. 7). This is followed by a list of names of saints in the genitive case, expressing the relation of dependence of the relics from the saints to whom they belong. ${ }^{21}$

Rather than pointing to an equation between names and relics, these examples make clear that both names and relics belong to the saints, and that the written names identify the saints whose relics are concealed inside. The relic list inscribed on the

LAVRENTII M(artyris) DE CRATICVLA S(ancti) LAVR(entii). My transcription, based on Lasko 1994, 127, fig. 177.

20 The reliquary is housed in the Treasury of the Cathedral of Minden. The text reads (from Wehking 1997, Nr.6): [HIC LEGVNTVR NOMI]NA S(an)C(t)ORVM Q[VO]/[R]VM / RELIQVI[E] HIC INTVS HABE/[N]TVR DE SEPVLCHR[O] D(omi)NI DE SANGV/[IN]E D(omi)NI DE S(ancto) PANCRATI[O] DE VESTIMENT/[O] MARIE DE S(ancto) SIGISM/V]NDO DE CORPO/[RE]S(ancti) VITI DE S(ancto) PETRO (ET) S (ancto) ANDREA D[E] / [S (ancto) M]AVRITIO (ET) SOCIIS EIVS DE S(ancto) Y/[...] TO (ET) DE S(ancto) [G]ORGONIO DE S(ancto) LAV(rentio) +.

21 The inscription reads (my transcription): HEC SVN/NT NO(min)A / ISTOR(um) / S(an)C(t)OR(um) / DE LIG/NO D(omi)NI // PETRI / ANDREE / IACOBI // STEP/HANI / GEORGI // LAVRE/NCII PANC/RACII / VITI / MART/INI / NICH/OLAI / LIVD/GERI. 
Borghorst Cross expresses the same sort of relationship between names and relics: by mentioning the names of the saints, writing acts as a material link that allows the reliquary's hidden content to emerge as a visible and identifiable presence on the surface of the cross. In this way, the group of relics is organized, fully made part of the reliquary's figural and symbolic composition, and intimately connected with the prayer that takes place in the same text. Seventeen relics are listed in a hierarchical order: first come two relics of the passion of Christ, then one item connected to the Virgin Mary, followed by the relics of three apostles and those of eleven martyrs and virgins. As Julia Smith pointed out in relation to inscriptions on altars, "this classification has been widely (although not universally) used since c. 800 and effectively recreates the Heavenly Jerusalem in the form of a list, exactly as litanies did". ${ }^{22}$ The collective invocation of saints that concludes the text reinforces the litany structure of the inscription, emphasizing the intercessory function of "those saints" whose relics had been placed in the cross, and of "all saints" to whom the prayer is addressed. The spatial distribution of the script makes clear that the saints' names and the prayer of Abbess Bertha are conceived as a unique text, that is, an intercessory relic list, working in conjunction with the inscription identifying the image of the principal intended beneficiary of the prayer. The writing of the name is a means to make the content of the figurative representation on the reliquary also present by means of letters, and to link it to the larger artistic ensemble: so, it is not just the image of a faithful, but that of "Bertha the Abbess", whose name is connected to both the framing inscription and the blessing hand of God. The image is placed just above the lower flask, in close proximity to the relics, but it is towards her written name that God's hand transmits the divine grace through gesture and contact. In the interlocking texts and imageries, the inscriptions, taken all together, reveal what is displayed on the cross, while also asserting the saints' presence as intermediators before God in the Court of Heaven and performing an intercessory function for the faithful, and in particular for the author of the pious gestures and the prayer represented upon, and made in front of, the inscribed cross. ${ }^{23}$

All inscriptions of the cross have been realized to identify a content and to make it part of a larger ensemble. Relics, patrons, angels, the community of the faithful and saints-they are all named and involved in the contextual web of relationships between the multiple components of the reliquary. The features shared by the inscriptions on the two sides also extend to the way in which the individual textual and visual elements combine to generate further meanings. As the foregoing has shown, writing is a material trace and a visual link that connects the identified image of Emperor Henry

22 Smith 2017. For the analysis of groups of saints in litanies from Carolingian Europe, see Krüger 2014.

23 This interpretation complements Gerevini 2014, 96. 
to both the reliquary and the angelic figures, and that connects these latter to one another in order to assert their identical nature and, perhaps, also to emphasize their symmetrical display. This display, I would suggest, may evoke the golden Cherubim of the biblical Ark, as in Exodus. ${ }^{24}$ On the horizontal arm, the orientation of the letters is possibly a device to strengthen the connection between the identified images of the saints and the relics collected in the central flask. Whether or not these texts and images were originally conceived as a unified programme, the inscriptions identify and pair the saints, with the Apostles Peter and Paul flanking the central vessel to convey the idea of the unity of the Church in the body of Christ, ${ }^{25}$ which the relic flask intended to evoke through its shape, colour, and position. ${ }^{26}$ On the back, the set of two inscriptions has to be seen as a coordinated attempt to make all the different elements communicate with each other, acting, as we shall see, also as a bridge between the two sides of the cross, and between the viewer and the cross.

The inscriptions would allow a reader to recognize the images depicted on the cross, or the relics displayed through the 'lens' of the reddened flasks, but they first of all make a (textual) content present in a specific place in the act of writing, as another means to materialize a message, a meaning, in a physical context. In this way, even when the reliquary was concealed from the viewer's eyes, this content persisted, materially inscribed on the cross and therefore present through its letters, as another meaningful component of its figural and symbolic programme. As noted above, the use of inscriptions was not obligatory, but the inclusion of writing allows a meaning to emerge in the sensory matter (also) through letters, adding an extra level of significance, both semantic and semiotic, to the object with which writing fuses by sharing the same medium and location. It is only in a second moment that these identified contents become, at least potentially, visible and legible, depending on the multiple and simultaneous ways in which the reliquary could have been accessed, as well as on the capacities of the viewer (close enough to the reliquary) to make sense of the text. ${ }^{27}$

Let us now turn to the visual features of the inscriptions, as it will bring the meaning expressed by the epigraphic presence to a further level of significance.

24 Exod. 25:18-20: "And you shalt make two cherubim of gold; of hammered work shall you make them, on the two ends of the mercy seat. Make one cherub on the one end and one cherub on the other end. Of one piece with the mercy seat shall you make the cherubim on its two ends. The cherubim shall spread out their wings above, overshadowing the mercy seat with their wings, their faces one to another; toward the mercy seat shall the faces of the cherubim be." The idea that the presence of angels on reliquaries suggests the Cherubim of the Ark is advanced by Cynthia Hahn; see Hahn 2012, 240-241; for portable altars in particular, see Hahn 2014, passim.

25 Cf. Thunø 2007, 28-32.

26 As Stefania Gerevini convincingly proposed, the visual analogy between the rock crystal vessel and the crucified Christ is suggested by the elongated shape of the ampulla, by its position at the center of the cross, and by the presence of the red textile inside the flask, see Gerevini 2014, 96.

27 For the exploration of these issues, see Frese/Keil/Krüger 2014; Keil et al. 2019. 


\section{Seeing the Cross}

Although all inscriptions have the primary function to identify a content, and work together as an ensemble to generate meanings, the specific textual contents and the visual nature of their design differs on the two sides. The letters' size, the technique by which the texts are executed, their content and spatial arrangement, suggest that the two groups of inscriptions did not have the same meanings and were not intended to be experienced in the same way. These variations were certainly deliberate and can be found in many other reliquaries of the Western medieval world. On the Borghorst Cross, however, they are particularly evident, raising questions about the possible meanings that underlay the practice of writing down words on the external surface of an artefact which not only was meant to be concealed, but also on occasions to be displayed in many different ways within a variety of devotional performances. ${ }^{28}$ Notwithstanding differences in contents, techniques and media, the inscriptions of the cross are comparable in a meaningful way, for they all seem to express the same sort of paradox: writing is present, but it does not always allow an immediate or easy access to its textual content.

On the front, the inscriptions are composed by short texts written in small script (ca. 3-5 mm). The texts, worked in repoussé technique, are almost indistinguishable from the embossed images with which they share the iconographical background. Even experienced readers (close enough to the object) must examine the composition of the front very closely to detect the minute serifed letters and separate them from the dense repoussé reliefs with which they are interlaced. Also, the use of gold does not facilitate the reading of the texts, working here even against their visibility, as the background is made of gold too. ${ }^{29}$ These features together suggest that the accessibility (visual and verbal) of the texts was not a primary concern. What mattered instead was the placement of specific identified images on the golden decorated surface of the cross. Medieval exegetes consistently associated gold with the splendour of the Holy City based on the description of its streets as paved in pure gold, as in the Book of Revelation. ${ }^{30}$ Gems and precious stones were also commonly associated with the Holy City and, more in general, with saints and paradise, a point to which I shall return below. In this way, the material out of which the inscriptions and the related

28 On the display and uses of reliquaries in the liturgy, see Hahn 2012, 145-160.

29 For the use of gold in inscriptions, its visual effects and symbolic properties according to Christian tradition, see Thunø 2007, 33; Thunø 2011.

30 Rev. 21:19-21: "The foundations of the wall of the city were adorned with every kind of jewel. The first was jasper, the second sapphire, the third agate, the fourth emerald, the fifth onyx, the sixth carnelian, the seventh chrysolite, the eight beryl, the ninth topaz, the tenth chrysoprase, the eleventh jacinth, the twelfth amethyst. And the twelve gates were twelve pearls, each of the gate made of a single pearl, and the street of the city was pure gold, like transparent glass". On the visual representations of the Heavenly Jerusalem in images, reliquaries, churches, and holy sites across western and eastern medieval Europe, see Kühnel/Noga-Banai/Vorholt 2014. 
images were made underlines and completes the meaning of the entire composition of the front, which was intended to present a vision of heaven with Christ at the centre as the unifying element, and with Emperor Henry as part of heaven.

The inscriptions on the back are engraved and occupy an extended portion of the surface. The letters are twice as big as those on the front (c. 10 versus c. $5 \mathrm{~mm}$ ). The contrast between the black filling and the gilded background strategically emphasizes the presence and visibility of writing. The same effect has the juxtaposition of the curvilinear forms of the images and the perpendicular rows of the script. Despite the ubiquitous and noticeable presence of writing, the cross's most dominant visual features are not the letters but rather the reddened relic flasks-a way to emphasize the contiguity between the two sides of the cross. ${ }^{31}$ Writing is here more visually imposing than on the front. Yet, the strategies of the presentation of the texts, namely the display of letters around the cross, can both facilitate and obfuscate access to the textual content. In other words, the valorization of the presence and visibility of writing does not necessarily correspond to a valorization of the (immediate) legibility of the text. One has to move the eyes across all the edges of the cross, or rotate the object, to find the starting point of the text and make sense of its content, slowly scrolling the inscription in a sort of physical and symbolic journey across the entire space of the cross. The use of the continuous script makes it difficult to detect the single words within the text. At the moment of the visual perception of the reliquary from this side, the whole text takes on more importance than its single parts. However, the clarity of letterforms and their visibility suggest an intention of legibility of the text for those who could access it. In both its text and layout, this inscription is also performative, asking the reader implicitly to move around the cross, or to move the cross, and mentioning the pious gestures made in front of the reliquary. By virtue of the length, placement, and clarity of the script, the name of "Bertha the Abbess" would be the only one immediately discernible. In this way, it can be read in concert with the relic list and the prayer, or work separately, as an independent text, for instance as a form of intercessory prayer which could be impressed on the viewers' eyes and souls. ${ }^{32}$

Whether or not the inscriptions were read, they collaborate in the visual impact of the reliquary and contribute to the spatial organization of the visual composition. In this way, writing functions as ornament, highlighting or creating the nodal points of the cross, its loci of meaning. The spatial arrangement of the letters around the perimeter of the cross is a way to reinforce its very shape, whilst the nominal inscription, in the perpendicular orientation of the script, redirects the viewer's attention towards the space comprised between the two rock crystal flasks: this is the only space of the cross in which the reddened vessels can be seen in conjunction with one another,

31 Cf. Gerevini 2014, 96-97.

32 A similar interest in the presentation of epigraphic prayers can be found, for instance, in inscriptions from medieval Georgia, see Eastmond 2015b, 79-80. 
and with the images of the two patrons who are depicted on either side of the cross, in spatial (and spiritual) relation with one another. Rather than prioritizing the visual appearance of the text over its content, the circular inscription on the back seems to express a sort of tension between legibility and ornament which other forms of writing across the medieval world present as well. ${ }^{33}$ Form and content of the framing inscription fuse with one another, shifting the balance between text, shape and meaning. In this way, the entire composition is brought into a more intricate dynamic, aimed ultimately at creating a portal between heaven and earth through which the faithful can have access to salvation, in a trajectory in which both writing and relics have a central place.

Not only does the circular arrangement of writing visually reinforce the shape of the cross, it also creates a frame for the sacred relics within, and for all that surrounds them on this side. Circular inscriptions can be found on many other reliquaries across the western medieval world. ${ }^{34}$ They are particularly recurrent on relic crosses and portable altars, two types of reliquaries that, perhaps more often than others, were inscribed with relic lists. The circular layout of writing, however, is not specific to relic lists, ${ }^{35}$ nor to inscriptions on reliquaries. Recent studies on medieval inscriptions have underlined the multiple symbolic meanings associated with circular alphabetical displays. They are typical of seals and, more significantly, find parallels with the 'alphabetic belts' which were traced on church floors during the liturgical ceremonies of the consecration of a church. ${ }^{36}$ It seems reasonable to suppose that the inscription on the Borghorst Cross also sought to emphasize its aura of authority, while acting as a "marker of sacredness", to use Vincent Debiais' incisive formulation. ${ }^{37}$ Seen from this perspective, the inscription is clearly much more than just a descriptive label for the relics. It would validate its textual content and in turn the sacred content of the magnificent container to which the text is attached and to which it refers, placing this content in a separated space and participating in the configuration of the meaning of the entire reliquary.

33 Cf. Grabar 1993, 45-118. Recent scholarship on medieval inscriptions has devoted considerable attention to the ways in which texts inscribed on monumental, extensive supports could play with the viewer, shifting emphasis between the textual content and its formal appearance. See for instance Eastmond 2015a; Debiais 2017b.

34 Cf. Chaganti 2008, 13-14.

35 See, for instance, two crosses from Oviedo (Spain): the Cross of the Angels (808) and the Cross of Victory (908), both presenting a circular inscription on the back; for the analysis of these crosses, see Schlunk 1950. A circular inscription can also be found on the cruciform casket of Paschal I from the Sancta Sanctorum, now in the Vatican Museums, see Thunø 2002, 79-117.

36 On the consecrational alphabet, see Treffort 2010. For the connections between alphabetic liturgical belts and circular displays of inscriptions on monuments, see Debiais 2017b, 295-297, with references to Christian exegesis of the alphabet. For the uses and meanings of the framing inscriptions in the western medieval world, see also Ingrand-Varenne 2017.

37 Debiais 2017b, 295. 
The idea of the inscription as a limen, protecting an inner space from an exterior one, is reinforced visually by the pairing of the text with the frame of precious stones that encloses what could be called the 'narrative' on the front. Their variety, beauty and spatial disposition around the perimeter of the cross may evoke the gems of the wall of the Heavenly Jerusalem as described in Revelation. ${ }^{38}$ According to John's vision, the foundations of the city wall were decorated with precious stones and had twelve gates, upon which the names of the Apostles of the Lamb were written. ${ }^{39}$ In its reference to the saints ("the names of those saints" which opens the relic list, and "these and all saints" to whom the prayer is addressed), and in the pairing of the written names with the gems, the inscription may evoke a parallel with the Holy City's wall, perhaps intending to represent the earthly counterpart of the gates of the Holy City, about which is said: "But nothing unclean will ever enter it, nor anyone who does what is detestable or false, but only those who are written in the Lamb's book of life" (Rev. 21:27). As both text and framing device, the inscription delimits, encloses, and, I would argue, even protects ${ }^{40}$ the sacred space of the cross where the relics are simultaneously contained and revealed through both the rock crystal and the written names of saints, asserting the participation of the relics that the names identify in the construction of the Heavenly Jerusalem.

The comparison with other eleventh-century cross reliquaries featuring relic lists (which are always displayed on the back of the crosses), underlines the function of the inscription as a device to establish a correlation between the two sides; as a frame to delimit, strengthen or even create an interior space; as a tool to direct the viewer's attention towards the centre of the cross, usually staging the commemoration of Christ's sacrifice. The Erpho Cross at Münster discussed above is an example for this (Fig. 6-7). Although writing is arranged here in horizontal rows, it circulates around a centre displaying the Lamb of God, as a counterpart to the body of the crucified Christ. Another cross now in the Kunstgewerbemuseum of Berlin, the so-called Guelph Cross (c. 1045), bears a relic list in the form of four names of saints in the genitive case; they are arranged, each on one arm, around a squared rock crystal window which may suggest the table of an altar (Fig. 8-9). ${ }^{41}$

38 Rev. 21:19-21; see above, Note 30.

39 Rev. 21:14: "And the wall of the city had twelve foundations, and on them were the twelve names of the twelve apostles of the Lamb."

40 The idea of a prophylactic function of inscriptions on reliquaries is suggestively reinforced by the inclusion of anathema formulas in the texts. In Germany, for instance, formulations warning against potential theft of the reliquary can be found in the inscription revolving around the upper panel of the portable altar of St Andrew in Trier (977-993), and in the text inscribed on a copper plate fixed on one of the sides of an eleventh-century portable altar from the former female collegiate church of Bad Gandersheim.

41 See, for instance, the rock crystal 'stone' on the top of the portable altar of Henry II at Munich, discussed above. This is however an exception in the large group of eleventh- and twelfth-century 


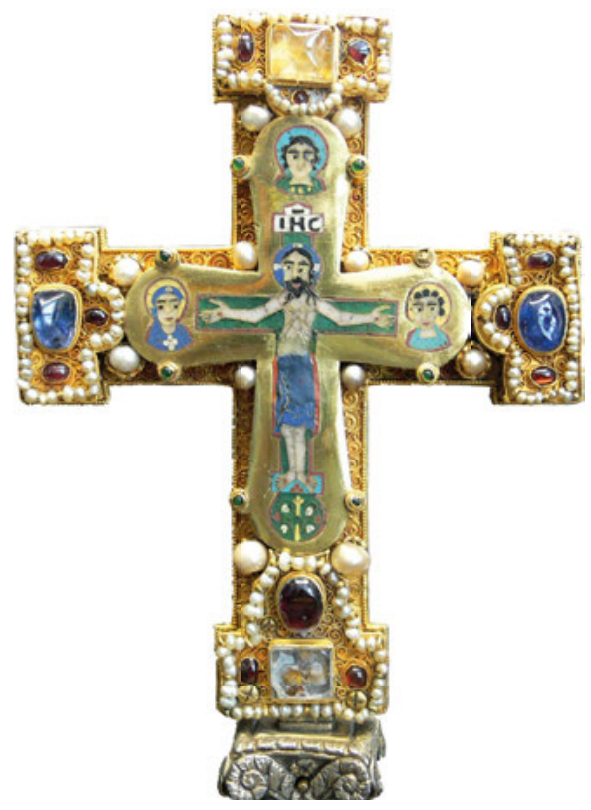

Fig. 8: Guelph Cross, reliquary, obverse. Berlin, Kunstgewerbemuseum.

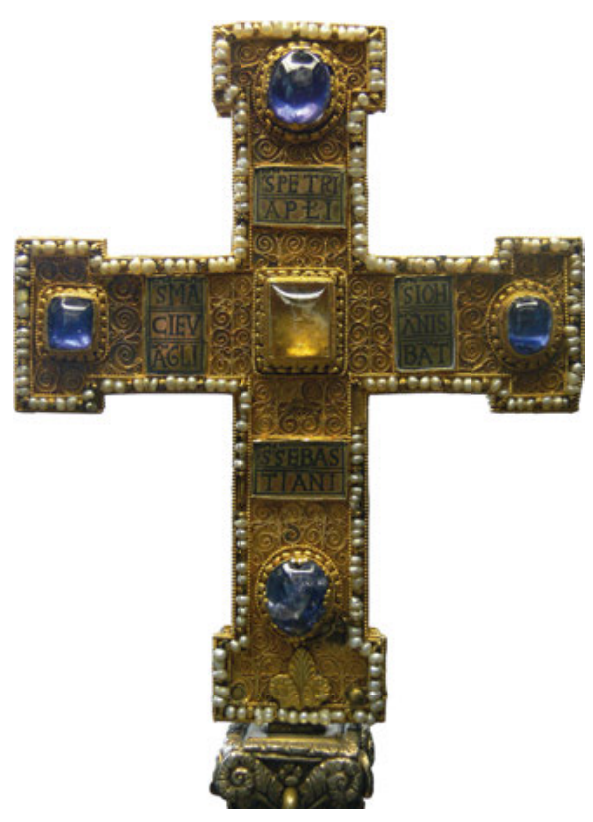

Fig. 9: Guelph Cross, reliquary, reverse. Berlin, Kunstgewerbemuseum.

However, perhaps the most striking comparison for the Borghorst Cross is the pectoral cross, reliquary, from St Servatius in Maastricht, executed around 1039 (Fig. 10-11). ${ }^{42}$ The list of relics that encircles the back of the reliquary is the visual pendant to the frame of gems on the front.

Thanks to the circular display of letters, the empty surface framed by the written words is no longer an indeterminate space, but becomes a suggestive space oscillating between presence and absence. ${ }^{43}$ The text suggests that this is the space of the altar, the holy table on which the body of Christ, and perhaps of all saints, is present and consumed. ${ }^{44}$ The formulation that opens the text, sub hanc cruce continentur reliquie,

portable altars from Germany, for which see Hahn 2014. For an overview of forms and contents of inscriptions on portable altars of the Middle Ages, see Favreau 2003.

42 The cross reliquary is now on display in the Treasury of the church of St Servatius in Maastricht. For a detailed analysis of the cross and its content, see Koldeweij 1985, 174-194.

43 The inscription works in a way similar to the frames surrounding the table of the portable altars, see Hahn 2014.

44 The text, in Latin, reads (my transcription): + SVB HA(n)/C CRVCE CONTI/NENTVR RELI/QVIE / DE LIGNO D(omi)NI / DE SEPVLCHRO D(omi)NI DE [GR/ATICV/L]A S(ancti) LAVRENTII S(ancti) FELICIS EP(iscop)I / PAVLINI EP(iscop)I / S(ancti) COR/NELII PAPE S(an)C(t)I / PAVLINI DIAC(oni). I propose the following translation: "Under this cross are contained the relics of the wood of the Cross, of the sepulcher of the Lord, of the grill of Saint Laurence, of Saint Felix bishop, of Paulinus bishop, of Saint Cornelius pope, of Saint Paulinus deacon”. 


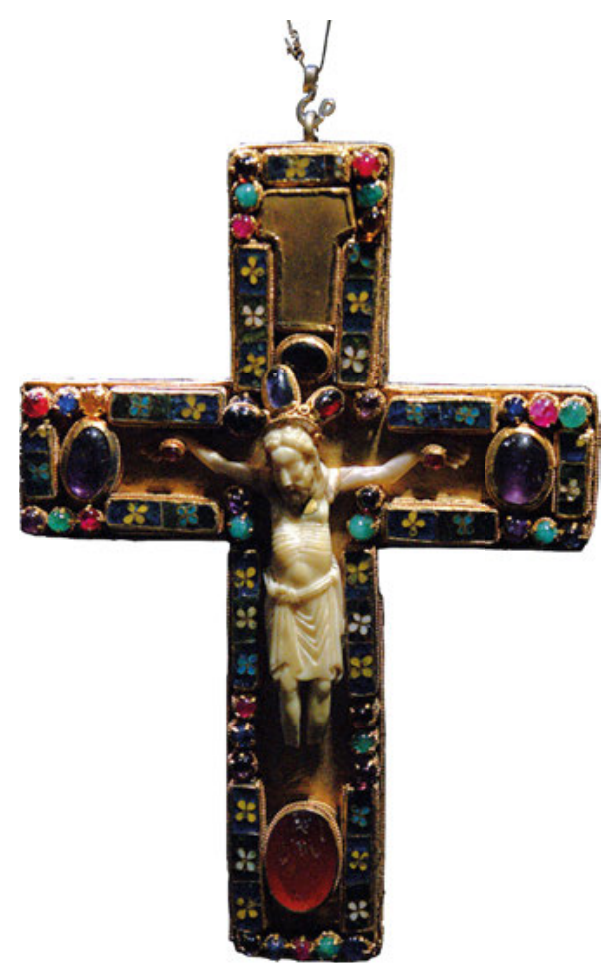

Fig. 10: Pectoral cross, reliquary, obverse. Maastricht, St Servatius, Treasury.

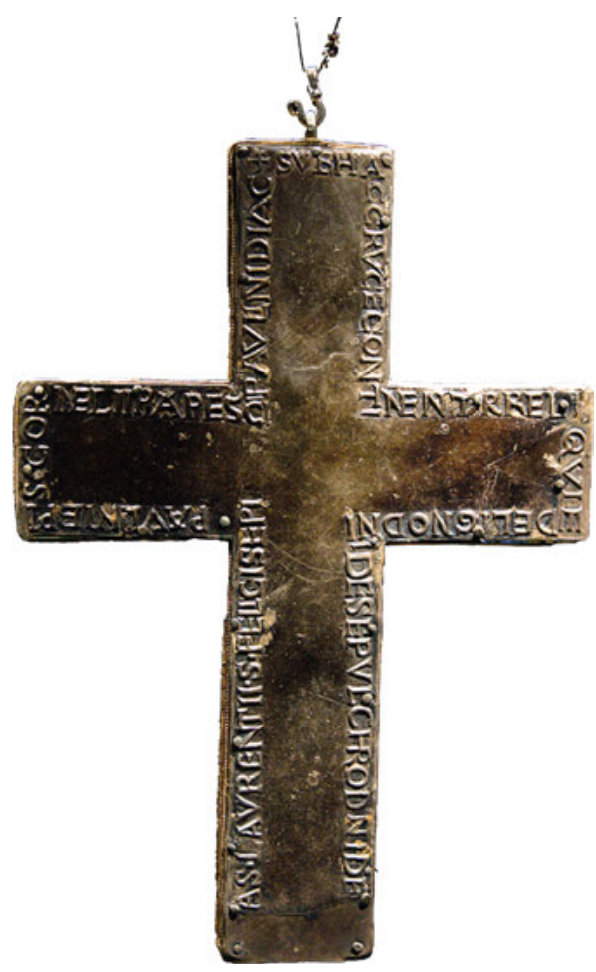

Fig. 11: Pectoral cross, reliquary, reverse. Maastricht, St Servatius, Treasury.

echoes the account in Revelation where the souls of the martyrs are present underneath the altar. ${ }^{45}$ The inscription steers an immediate association between the Cross and the altar, reinforcing the idea of the participation of the relics that are contained "under this cross", in the sacred union of saints that is concealed under the altar. Furthermore, the presence of writing as opposed to the empty space of the centre may invite the viewer to see the framing inscription as the substitute of its content. ${ }^{46}$

On the Borghorst Cross, the obscured visibility of the relics leaves the viewer only with the inscription pointing to a content which is physically inside the frame: the relics in the reddened flasks, the identified image of Abbess Bertha, and the figural representation of the descent of the Holy Spirit onto human beings, a theme featured here through the Christian iconography of the lignum vitae bringing together the Old and New Testaments' meaning of sacrifice. At the same time, the inscription helps the viewer in perceiving the continuity between the front and the back through the

45 Rev. 6:9: "When he opened the fifth seal, I saw under the altar the souls of those who had been slain for the word of God and for they witness they had borne".

46 Cf. Chaganti 2008, 13-14. 
unifying element of the rock crystal. On this level, writing works in concert with the transparent stones incorporated into the cross. Seeing the inscription means to move beyond the inscription and to embrace the cross as a whole. One may assume that the faithful's eyes would gaze into the holiest space of the reliquary, seeing, reading, and ultimately "imagining" the presence of the saintly court on earth through the inscribed reliquary. If so, the inscription may work ultimately to construct the reliquary as a space of imagination and salvation, a sort of passage for the faithful to access and touch heaven through the contemplation of the reliquary. ${ }^{47}$

Thanks to its visibility and layout, writing helped organize the reliquary's visual appearance, and this could affect the way in which the inscribed artifact was seen and experienced, leading viewers through the cross in many ways. The pairing of the two sides around a sacred centre which is defined, or reinforced, by the inscription, may encourage the viewer to move around the cross, or to rotate the cross, and in so doing the inscription creates a dynamic space for the faithful in which the relics were possibly intended to be imagined in a spiritual sense, rather than physically seen, as an image of the body of Christ, whose sacrifice was the sign of the unity of the Church. Medieval commentators of the Old Testament texts consistently interpreted the Ark of the Covenant described in Exodus 25 as a prefiguration of the Church. ${ }^{48}$ As Cynthia Hahn showed, explicit references to the biblical Ark can indeed often be found on reliquaries, particularly on portable altars with their ubiquitous angels evoking the Cherubim, and with their golden frames for the altar stone. ${ }^{49}$ Similarly, as noted above, it may be that the two angels represented on the front of the Borghorst Cross should be recognized as the Cherubim that guard and protect the Ark. The nominal inscription qualifying the two celestial figures as "angels" is probably the most unnoticeable text inscribed on the reliquary. Nonetheless, it exists and persists on the cross as a graphic presence, "creating" the figure of the angels maybe as a progeny of their biblical archetype, and in turn creating the reliquary as a space of salvation for the Christian community.

\section{Conclusions}

This paper hoped to give some insight into the variety of ways in which the inscriptions could contribute to the multiple functions, at once strongly pragmatic and symbolic, of the reliquary. Besides their function as containers that simultaneously concealed and staged the relics, reliquaries were also tools that assured the portability of relics and their participation in the liturgy; they were devices that elicited veneration

47 Cf. Hahn 2012, 209-221.

48 Appleby 1995, 434-435. See also Palazzo 2008.

49 Hahn 2014, 47, 56; Hahn 2012, 241-242. 
through their visual and material features. In the case of the Borghorst Cross, like in many others, the iconographic and visual programme includes inscriptions. The recurrence and variety of forms and contents of the inscriptions which were placed on reliquaries increasingly often with the approach of the eleventh century, testify to the degree in which Christian patrons and commissioners exploited the multiple possibilities of (epi-)graphic expressions to construct the forms and meaning of these artefacts.

The inscriptions and their reliquaries were conceived together, and worked as parts of a complex system that expanded from the reliquary to the ritual setting, including other inscriptions, officiating priests and people attending, but also images, materials, letters, shapes, conceptual contents, colours, light effects, gestures, the multifarious liturgical furnishings, and so on. Within the context of the church building, all these elements worked in concert to shape the space where the holy relics of the saints were kept and shown as a sacred presence for an audience of Christian worshippers. Inscriptions took part in this process in a variety of ways, not as disembodied textual contents, but as integral parts of the larger system to which they belonged. This paper has explored some of the ways in which inscriptions could interact with the reliquary, leaving out for the moment the question of the possible interactions of the inscribed reliquary with the intended audiences within specific ritual contexts.

The epigraphic programme of the Borghorst Cross has been used as an example to explore some aspects that may be meaningful also for the understanding of the epigraphic programmes of other reliquaries of the same period, particularly those of relic crosses. Even if each reliquary is in a sense unique, the inscriptions which are placed on them seem to work in similar directions and on multiple levels simultaneously. Between presence, display, and viewer, they implicitly remind the faithful of the ultimate purpose of the larger system of the Church to which they belong. That is, the achievement of human salvation.

\section{Bibliography}

Althoff, Gerd / Siart, Olaf (eds.) (2012), Goldene Pracht. Mittelalterliche Schatzkunst in Westfalen (Catalogue of the exhibition, LWL-Landesmuseum für Kunst und Kulturgeschichte, Münster, Cathedral of St Paulus, Münster, 26. February-28. May 2012), Munich.

Appleby, David F. (1995), "Abbot Hrabanus, and the Ark of the Covenant Reliquary", in: American Benedictine Review 46, 419-443.

Bagnoli, Martina (2011), "The Stuff of Heaven. Materials and Craftsmanship in Medieval Reliquaries", in: Martina Bagnoli, Holger A. Klein and Charles Griffith Mann (eds.), Treasures of Heaven. Saints, Relics, and Devotion in Medieval Europe (Catalogue of the exhibition, The Cleveland Museum of Art, 17. October 2010-17. January 2011, The Walters Art Museum, Baltimore, 13. February 2011-15. May 2011, The British Museum, London, 23. June 2011-9. October 2011), London, 137-147. 
Bagnoli, Martina/ Klein, Holger A. / Mann, Charles Griffith (eds.) (2011), Treasuries of Heaven. Saints, Relics, and Devotion in Medieval Europe (Catalogue of the exhibition, The Cleveland Museum of Art, 17. October 2010-17. January 2011, The Walters Art Museum, Baltimore, 13. February 2011-15. May 2011, The British Museum, London, 23. June 2011-9. October 2011), London.

Berti, Irene/Bolle, Katharina/Opdenhoff, Fanny/Stroth, Fabian (eds.) (2017), Writing Matters. Presenting and Perceiving Monumental Inscriptions in Antiquity and the Middle Ages (Materiale Textkulturen 14), Berlin / Boston.

Boston, Karen (2003), “The Power of Inscriptions and the Trouble with Texts”, in Antony Eastmond and Liz James (eds.), Icon and Word: The Power of Images in Byzantium: Studies Presented to Robin Cormack, Aldershot, 35-57.

Chaganti, Seeta (2008), The Medieval Poetics of Reliquaries: Enshrinement, Inscription, Performance, New York (NY).

Debiais, Vincent (2017a), La croisée des signes. L'écriture et les images médiévales (800-1200), Paris.

Debiais, Vincent (2017b), "Writing on Medieval Doors. The Surveyor Angel on the Moissac Capital (ca. 1100)”, in: Irene Berti, Katharina Bolle, Fanny Opdenhoff and Fabian Stroth (eds.), Writing Matters. Presenting and Perceiving Monumental Inscriptions in Antiquity and the Middle Ages (Materiale Textkulturen 14), Berlin / Boston, 285-308.

Eastmond, Antony (ed.) (2015a), Viewing Inscriptions in the Late Antique and Medieval World, New York (NY).

Eastmond, Antony (2015b), “Textual Icons: Viewing Inscriptions in Medieval Georgia”, in: Antony Eastmond (ed.), Viewing Inscriptions in the Late Antique and Medieval World, New York, 76-98.

Eickel, Hans (1968), “Das Borghorster Stiftskreuz”, in: 1000 Jahre Borghorst. 968-1968, ed. by Stadt Borghorst, Münster, 44-55.

Favreau, Robert (2003), “Les autels portatifs et leurs inscriptions”, in: Cahiers de civilisation médiévale 46, 327-352.

Frese, Tobias / Keil, Wilfried E. / Krüger, Kristina (eds.) (2014), Verborgen, unsichtbar, unlesbar. Zur Problematik restringierter Schriftpräsenz (Materiale Textkulturen 2), Berlin / Munich / Boston.

Gerevini, Stefania (2014), "Christus crystallus. Rock Crystal, Theology and Materiality in the Medieval West”, in: James Robinson, Lloyd de Beer and Anna Harnden (eds.), Matter of Faith: An Interdisciplinary Study of Relics and Relic Veneration in the Medieval Period, London, 92-99.

Grabar, Oleg (1993), The Mediation of Ornament (Bollingen series XXXV 38), Princeton (NJ).

Hahn, Cynthia (2012), Strange Beauty. Issues in the Making and Meaning of Reliquaries, 400-circa 1204, Pennsylvania (PN).

Hahn, Cynthia (2014), Portable Altars (and the Rationale): Liturgical Objects and Personal Devotion, in: Poul Grinder-Hansen (ed.), Image and Altar 800-1300 (Papers from an international Conference in Copenhagen, 24.-27. October 2007), Copenhagen, 45-64.

Hostetler, Brad (2012), “The Limburg Staurotheke: A Reassessment”, in: Athanor 30, 7-13.

Ingrand-Varenne, Estelle (2017), “Inscriptions encadrées/encadrantes. De l'usage du cadre dans les inscriptions médiévales”, in: Christiane Deloince-Louette, Martine Furno and Valérie MéotBourquin (eds.), Apta compositio. Formes du texte latin au Moyen Âge et à la Renaissance, Genève, 69-90.

Jázai, Géza (1988), Kath. Pfarrkirche und Schatzkammer St. Nikomedes Steinfurt-Borghorst, Munich/ Zürich.

Keil, Wilfried E. / Kiyanrad, Sarah / Theiss, Christoffer / Willer, Laura (eds.) (2019), Zeichentragende Artefakte im sakralen Raum. Zwischen Präsenz und UnSichtbarkeit (Materiale Textkulturen 20), Berlin/Boston.

Koldeweij, Jos (1985), Der goude Sent Servas, Aassen / Maastricht. 
Krüger, Astrid (2014), “La Cour céleste mise en système. La mémoire collective dans les litanies du VIII et du IXe siècle”, in: Olivier Marin and Cécile Vincent-Cassy (eds.), La Cour céleste. La commémoration collective des saints au Moyen Age et à l'époque moderne, Turnhout.

Künel, Bianca/Noga-Banai, Galit/Vorholt, Hanna (eds.) (2014), Visual Constructs of Jerusalem, Turnhout.

Kurtze, Anne (2017), Durchsichtig oder Durchlässig. Zur Sichtbarkeit der Reliquien und Reliquiare des Essener Stiftsschatzes im Mittelalter (Diss. Potsdam, 2015), Petersberg.

Lasko, Peter (1994), Ars Sacra 800-1200, Yale (New Heaven, CT).

Palazzo, Eric (2008), L'espace rituel et le sacré dans le christianisme. La liturgie de l'autel portatif dans l'Antiquité et au Moyen Age, Turnhout.

Pallottini, Elisa (2018), "Monumentalisation et mise en scène des saints dans le lieu de culte. Les listes épigraphiques de reliques en l'Occident Médiéval (viiie-xiie siècle)", in: Pierre Chastang and Laurent Feller (eds.), Le pouvoir des listes au Moyen Âge, vol.1: Écritures de la liste, Paris (forthcoming).

Reudenbach, Bruno (ed.) (2009), Karolingische und ottonische Kunst (Geschichte der bildenden Kunst in Deutschland 1), Munich / Berlin / London / New York (NY).

Riccioni, Stefano (2006), Il mosaico absidale di S. Clemente a Roma. Exemplum della Chiesa Riformata, Spoleto.

Roll, Axel, “Das Borghorster Stiftskreuz ist wieder da" <http://www.wn.de/Muensterland/KreisSteinfurt/Steinfurt/2017/02/2699113-Video-Millionenschwerer-Kirchenschatz-Das-

Borghorster-Stiftskreuz-ist-wieder-da> (last accessed 16.02.2017).

Schlunk, Helmut (1950), "The Crosses of Oviedo: A Contribution to the History of Jewelry in Northern Spain in the Ninth and Tenth Centuries", in: The Art Bulletin 32 (2), 91-114.

Smith, Julia (2017), "Eleventh-Century Relic Collections and the Holy Land”, in: Renana Bartal, Neta Bodner and Bianca Kühnel (eds.), Natural Materials of the Holy Land and the Visual Translations of Place, $500-1500$, London.

Treffort, Cécile (2010), “Opus litterarum. L'inscription alphabétique et le rite de consécration de l'église (ixe-xiie siècle)”, in: Cahier de civilisation médiévale 53, 153-180.

Thunø, Erik (2002), Image and Relic. Mediating the Sacred in Early Medieval Rome, Roma.

Thunø, Erik (2007), “Looking at Letters. 'Living Writing' in S. Sabina in Rome”, in: Marburger Jahrbuch für Kunstwissenschaft 34, 19-42.

Thunø, Erik (2011), “Inscription and Divine Presence: Golden Letters in the Early Medieval Apse Mosaic", in: Word and Image 27, 279-291.

Wehking, Sabine (1997), Die Inschriften der Stadt Minden (Deutsche Inschriften 46), Wiesbaden.

\section{Photo Credits}

Fig. 1-5: P. Timmerhues (c) Katholisch in Steinfurt.

Fig. 6: Joachim Schäfer / Ecumenical Sacred Lexicon.

Fig. 7: Stadt Münster.

Fig. 8, 9: Wikimedia Commons.

Fig. 10, 11: Elisa Pallottini. 